\title{
Leachability of Oil Shale Ash from Isfir Al-Mahata Oil Shale, Southern Jordan
}

\author{
Hani M. Alnawafleh', Mohammad S. Al-Harahsheh², Adnan M. Al-Harahsheh ${ }^{3}$ \\ ${ }^{1}$ Department of Mining and Mineral Engineering, Al-Hussein Bin Talal University, Ma'an, Jordan \\ ${ }^{2}$ Department of Chemical Engineering, Jordan University of Science and Technology, Irbid, Jordan \\ ${ }^{3}$ Department of Chemical Engineering, Mutah University, Karak, Jordan \\ Email: Hanialnawafleh@ahu.edu.jo
}

How to cite this paper: Alnawafleh, H.M., Al-Harahsheh, M.S. and Al-Harahsheh, A.M. (2016) Leachability of Oil Shale Ash from Isfir Al-Mahata Oil Shale, Southern Jordan. Journal of Minerals and Materials Characterization and Engineering, 4, 292-303. http://dx.doi.org/10.4236/jmmce.2016.45026

Received: August 27, 2016

Accepted: September 23, 2016

Published: September 26, 2016

Copyright $\odot 2016$ by authors and Scientific Research Publishing Inc. This work is licensed under the Creative Commons Attribution International License (CC BY 4.0).

http://creativecommons.org/licenses/by/4.0/

c) (†) Open Access

\begin{abstract}
This paper presents the first study on the oil shale (OS) ashing and OS ash leachability of Jordanian OS located further in the south. The studied OS is from Isfir Al-Mahata subsurface OS located $10 \mathrm{~km}$ south of Ma'an. Chemical and physical characterization of the OS ash was performed and compared with original OS. Ashing OS was conducted at different temperatures. Important parameters affecting OS ash leachability were also investigated. The leachability of certain heavy metals was investigated based on clear leaching protocol. The Fisher Assay analysis result indicates that this OS type has quite higher moisture content, lower oil content, and higher spent shale compared with other Jordanian oil shales. Ashing of OS at higher temperatures $\left(950^{\circ} \mathrm{C}\right)$ resulted in the disappearance of silica, due to its complete reaction with lime and $\mathrm{Al}$, and formation of Anhydrite and cement materials like, Portland cement. The leachability analysis indicates that for most elements the leachability is high at low $\mathrm{pH}$. The released heavy metals concentrations are below EPA limits. Chromium and lead are leached out more than other elements with the exception at low $\mathrm{pH}$. In general, the higher the ashing temperature is, the lower the release of elements is. The chemical composition of the ash and the leachability results suggests that it has high fixing capacity toward the heavy metals present in the ash.
\end{abstract}

\section{Keywords}

Jordan, Oil Shale, Leachability, Ash, Heavy Metals

\section{Introduction}

Enormous research work and feasibility studies have been carried out on the Jordanian OS. This indigenous natural fossil fuel remains without utilization. Huge OS reserves 
are reported to cover large area of the country [1]. The most studied OS in Jordan is that located in central part which has favorable mining conditions [2]. Jordanian OS is kerogen-rich bituminous limestone of the Muwaqqar Chalk-Marl Formation formed within anoxic environment during the Maastrichtian and Paleocene times [3] [4]. Kerogen in OS yields petroleum-like hydrocarbons via destructive distillation by heat at about $500^{\circ} \mathrm{C}$ [5].

Oil shale development in Jordan requires complex and expensive facilities. Serious economic, environmental, and social implications for Jordan and its people are expected [6]. Among the most important utilization methods of OS are retorting and direct burning. The OS ash produced via such methods resulted in significant environmental problems. One major environmental problem is the heavy metal release [5]. Oil shale ash management is a wide field and the disposal of OS ash is costly, therefore, research is focusing on the benefit from OS ash in wide range of applications such as asphalt pavement construction and concrete industry. An example on the use of Jordanian oil shale ash in Portland cement concrete is that study reported by Smadi and Haddad [7]. Atmospheric emissions of $\mathrm{CO}_{2}$ produced from the oil shale combustion processes are considered as a serious problem [8]. The OS ash is found to be very efficient in removing most of $\mathrm{Pb}^{2+}$ ions from influent solutions [5].

Heavy metals found in OS ash could be released to the surrounding environment including surface and groundwater recourses [9]-[12]. Leachability of these heavy metals is closely related to the phases to which they are associated in addition to $\mathrm{pH}$ of the leaching environment [13]. Al-Harahsheh et al. [14] studied the leachability of heavy metals and major anions from Jordanian El-Lajjun spent oil shale after combustion and they reported that the level of heavy metals increases as the temperature of the ashing process increases. Based on their study, no significant metal release from the ashed OS has reported. Compared with the EPA limits for drinking water, El-Lajjun OS ash has low concentrations of trace elements [14]. The OS in the southern part of Jordan has not been studied from the ashing and leachability point of view. It is the aim of this research paper to investigate the ashing of OS form Isfir Al-Mahata subsurface OS and to study its leachability. The effect of some parameters such as particle size, mixing time, temperature and $\mathrm{pH}$ on OS ash leachability is considered.

\section{Material and Methodology}

\subsection{Oil Shale Sample Type}

Oil shale composite sample was provided from OS core interval of Isfir-1 borehole drilled in Isfir Al-Mahata OS south of Ma'an in the southern region of Jordan (Figure 1). The representative sampling interval is 158 - 161 meters below surface. Field inspection by authors identified the OS type as dark gray, hard fossiliferous bituminous chalk marl.

\subsection{Material Characterization Methodology}

Oil shale sample was firstly cleaned and then dried. One thin section has been prepared 


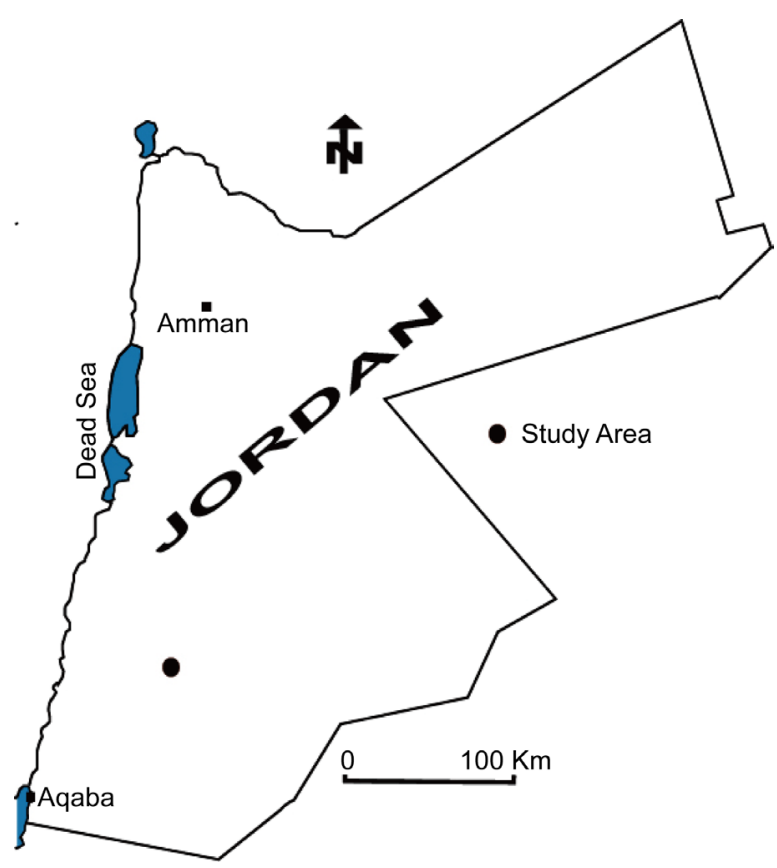

Figure 1. Location of Isfir Al-Mahata in southern Jordan.

and studied under the transmitted white light microscope. Part of the sample was crushed then pulverized. The pulverized OS sample was then sieved to several particle size fractions. The bulk density of the sample was determined through the density apparatus. Organic matter $(\mathrm{OM})$ content is inferred from the total organic carbon content (TOC) that is measured via carbon determinator. Elements quantitative analysis was obtained by $\mathrm{x}$-ray fluorescence instrument. The X-ray powder diffractometer (XRD) was used for mineral phase identification. The quality of OS is inferred from the Fisher Assay analysis that is obtained via the Fisher Assay apparatus according to ISO 647 by thermal cracking method.

\subsection{Ashing Process}

Ashing process was performed according to standard procedure reported by Harahsheh et al. [14]. Samples of 5 grams of the finely comminuted OS were placed in a ceramic plate, which were then heated in a carbolite furnace to different temperatures namely $550^{\circ} \mathrm{C}, 750^{\circ} \mathrm{C}$ and $950^{\circ} \mathrm{C}$. A heating rate of $10^{\circ} \mathrm{C} / \mathrm{min}$ was used for this purpose. The ashed samples were kept isothermally at the required temperature for two hours and then cooled to room temperature. The ashed OS samples were analyzed for their chemical and mineralogical content by using ICP-MS and XRD techniques. Finally, samples were sieved to wide range of particle sizes as follow 0 - 45, 45 - 125, 125 - 500, 250 - 500, $500-710,710-1400,1400-2000$, and $>2000 \mu \mathrm{m}$. The size $710-1400 \mu \mathrm{m}$ is selected to perform the leaching experiments.

\subsection{Leaching Process}

The investigated parameters and leaching methodology conditions followed are pre- 
sented in Table 1 . Dried ashed OS (approximately $1 \mathrm{~g}$ ) were placed in a volumetric flask $(100 \mathrm{ml})$ and filled with distilled water to the $100 \mathrm{ml}$ mark. Samples were soaked with regular shaking. The mixture was then filtered out using 0.5 micron filter paper. Leachate was then analyzed using ICP-MS. Distilled water was used as the blank. The $\mathrm{pH}$ and conductivity of the resulted solution (leachate) were also determined.

\section{Results and Discussion}

\subsection{Characterization of Original Oil Shale}

The bulk density of OS was found to be $1.4 \mathrm{~g} / \mathrm{cm}^{3}$. This is quite lower than that reported for similar material from other OS deposits in Jordan by Alali [2]. The TOC content is $8 \%$. The petrographical analysis (Figure 2) shows that the studied OS is characterized as fine-grained clacitic matrix embedded with planktonic foraminifera shells and phosphatic bones, foram's chambers are filled with secondary calcite. The mineral matrix consists of calcitic shell fragments, OM, with minor amounts of quartz, clay and apatite.

Table 1. Investigated parameters and leaching process conditions.

\begin{tabular}{|c|c|c|}
\hline $\begin{array}{l}\text { Investigated } \\
\text { parameters }\end{array}$ & Conditions & Other setup conditions \\
\hline 1. Mass (g) & Different masses $(1,2,3,4) \mathrm{g}$ & $\begin{array}{l}\text { Volume }(100 \mathrm{ml}), \text { time }(5 \mathrm{hrs}), \mathrm{rpm}(700) \\
\text { size }(710-1400) \mu \mathrm{m} .\end{array}$ \\
\hline 2. Size $(\mu \mathrm{m})$ & Different sizes $(\mu \mathrm{m})$ & Volume (100 ml), time (5 hrs), mass ( $1 \mathrm{~g})$, rpm (700). \\
\hline 3. Time (hr) & $\begin{array}{l}\text { Different time }(1,2,3,5,7,18,24) \\
\text { hrs. }\end{array}$ & $\begin{array}{l}\text { Volume }(100 \mathrm{ml}), \text { mass }(1 \mathrm{~g}), \mathrm{rpm}(700) \\
\text { size }(710-1400 \mu \mathrm{m})\end{array}$ \\
\hline $\begin{array}{l}\text { 4. Speed of } \\
\text { mixing }(\mathrm{rpm})\end{array}$ & Different rpm $(300,500,900,1100)$ & $\begin{array}{l}\text { Volume }(100 \mathrm{ml}), \text { mass }(1 \mathrm{~g}) \text {, time }(5 \mathrm{hrs}) \\
\qquad \text { size }(710-1400 \mu \mathrm{m})\end{array}$ \\
\hline 5. $\mathrm{pH}$ test & $\begin{array}{l}\mathrm{pH} \text { of the water adjusted by } \mathrm{HCl} \\
\text { and } \mathrm{NaOH} \text { solutions }\end{array}$ & $\begin{array}{c}\text { Volume }(100 \mathrm{ml}) \text {, mass }(1 \mathrm{~g}), \mathrm{rpm}(700) \text {, time }(5 \mathrm{hrs}) \text {, } \\
\text { size }(710-1400 \mu \mathrm{m})\end{array}$ \\
\hline $\begin{array}{c}\text { 6. Effect of } \\
\text { temperature on } \\
\text { pH value }\end{array}$ & Temperature and $\mathrm{pH}$ & $\begin{array}{c}\text { Volume }(100 \mathrm{ml}), \text { mass }(1 \mathrm{~g}) \text {, size }(710-1400 \mu \mathrm{m}) \text {, } \\
\text { time }(3 \mathrm{hrs}) \text {, and } \mathrm{rpm}(700)\end{array}$ \\
\hline
\end{tabular}

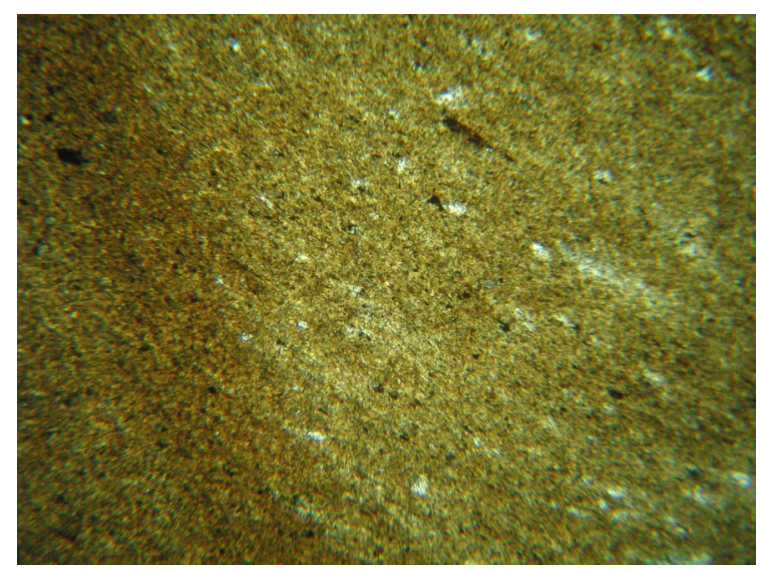

Figure 2. Photograph of oil shale sample under TWLM and $4 \times$ magnification. 
The results of Fisher assay analysis is presented in Figure 3. Over all, this OS type has quite higher moisture content, and lower oil content compared with that reported for similar material from Jordan by Alali [2] and Ibrahim and Jaber [5]. For the whole borehole, Alnawafleh et al. [15] reported that the oil content of OS in this borehole varies from $6 \%$ in the first 80 meters OS section to $11 \%$ in the remaining OS part.

The main mineral phases identified Via XRD analysis (Figure 4) in the original OS are; calcite, silica as quartz, phosphates as apatite, and minor amounts of clay minerals and pyrite.

The average content (wt\%) of selected metal oxides in the studied OS is presented in Table 2. The chemistry of this type of OS differs from that reported for central Jordan

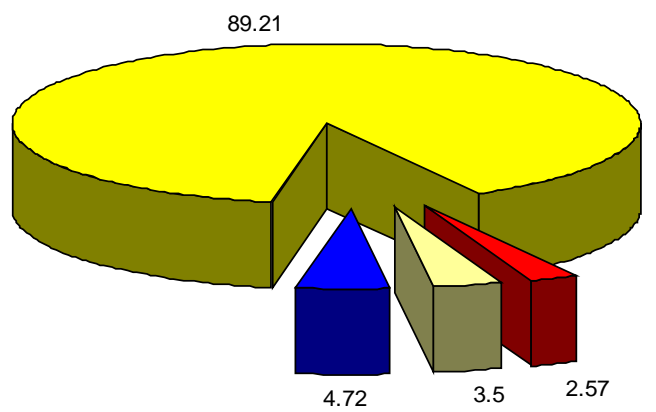

$\square$ Total Water Wt \% $\quad \square$ Total Oil wt \% $\quad \square$ Spent Shale Wt \%

Gas Loss Wt \%

Figure 3. Fisher Assay analysis results.

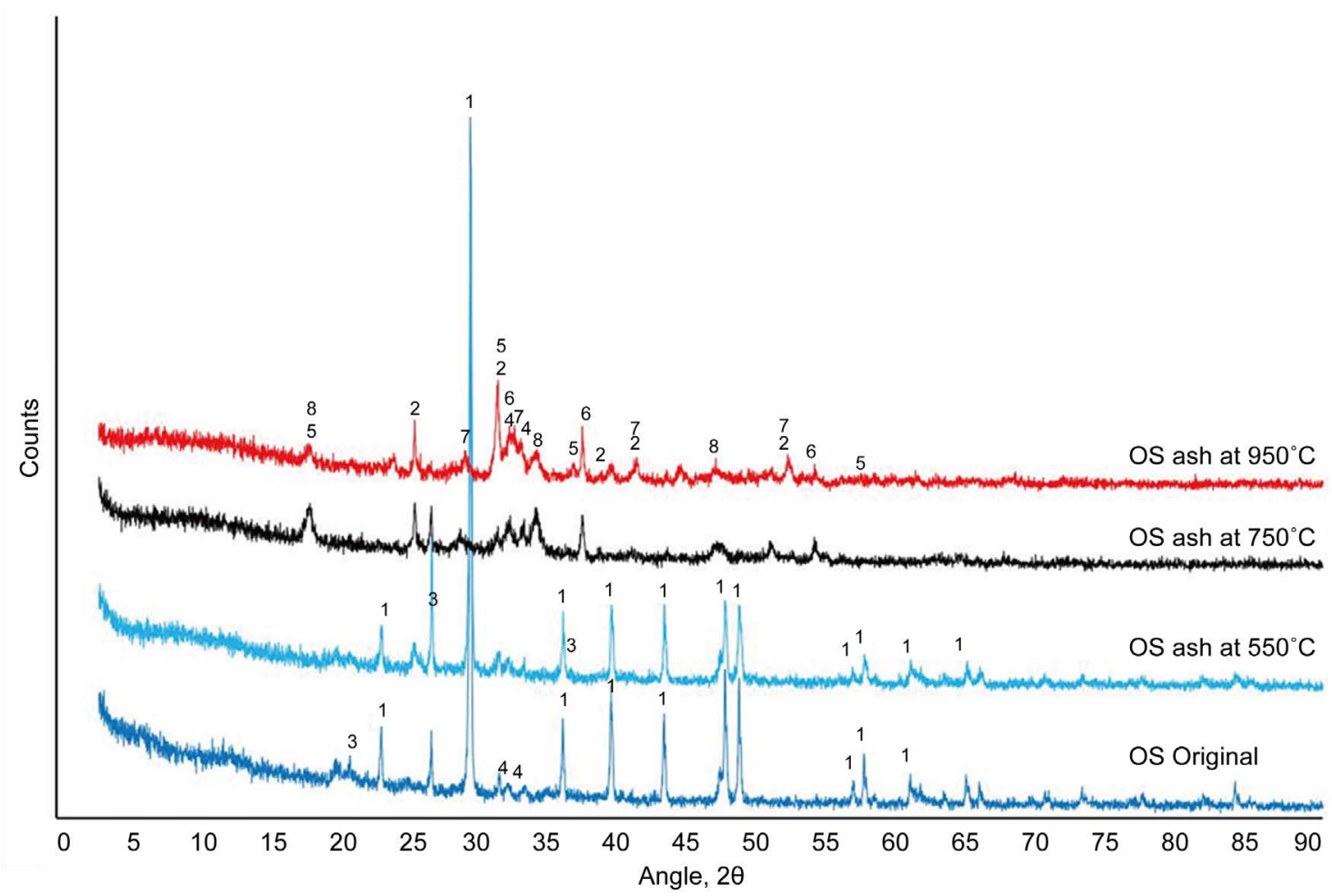

Figure 4. X-Ray diffraction patterns. 1-Calcite, 2-Anhydrite $\left(\mathrm{CaSO}_{4}\right), 3-\mathrm{Quartz}\left(\mathrm{SiO}_{2}\right), 4-\mathrm{Apatite}, 5-\mathrm{Maynite}$, 6-Lime, 7-Dicalcium silicate $\left(\mathrm{Ca}_{2} \mathrm{SiO}_{4}\right)$ and tricalcium silicate $\left(\mathrm{Ca}_{3} \mathrm{SiO}_{5}\right)$. 
Table 2. Average content (wt \%) of selected element oxides in original oil shale.

\begin{tabular}{|c|c|c|c|c|c|c|c|c|c|c|}
\hline $\mathrm{Fe}_{2} \mathrm{O}_{3}$ & $\mathrm{MnO}$ & $\mathrm{TiO}_{2}$ & $\mathrm{CaO}$ & $\mathrm{K}_{2} \mathrm{O}$ & $\mathrm{P}_{2} \mathrm{O}_{5}$ & $\mathrm{SiO}_{2}$ & $\mathrm{Al}_{2} \mathrm{O}_{3}$ & $\mathrm{MgO}$ & $\mathrm{Na}_{2} \mathrm{O}$ & L.O.I \\
\hline$\%$ & $\%$ & $\%$ & $\%$ & $\%$ & $\%$ & $\%$ & $\%$ & $\%$ & $\%$ & $\%$ \\
\hline 1.94 & 0.01 & 0.20 & 28.65 & 0.19 & 1.16 & & 5.92 & 0.42 & 0.15 & 49.72 \\
\hline
\end{tabular}

OS since this type of OS is rich in terrestrial material indicators [15]. One serious disadvantage of Jordanian OS is the high sulfur content [6]. High sulfur content makes the oil corrosive and unstable. Special refining and upgrading requirements increase the cost of refining [16] [17].

\subsection{Ashing Results}

The XRD results of OS ash resulted from ashing OS samples at different temperatures are shown in Figure 4. The XRD patterns of OS ashes are compared with XRD pattern for original OS. Mineral phase transformations are clearly indicated from the XRD patterns. Ashing $\mathrm{OS}$ at $550^{\circ} \mathrm{C}$ did not result in any major change in the mineralogical composition except that the intensity of the major peaks for calcite, phosphate, and quartz has increased due to the loss of $\mathrm{OM}$, it is also expected that the clay minerals such as kaolinite were transformed into amorphous phases. On the other hand, ashing OS at $750^{\circ} \mathrm{C}$ resulted in the appearance of calcium silicate, aluminium silicate and lime, and the disappearance of calcite. Above the temperature of $700^{\circ} \mathrm{C}$ calcium carbonate present in OS starts to decompose to $\mathrm{CaO}$ and $\mathrm{CO}_{2}$ [14]. At this temperature, considerable part of the quartz has reacted with calcium oxide and aluminium oxide to form silicates (see Reactions 1 and 2 as an example); smaller part of this quartz still present in the ash. Finally, OS ashed at $950^{\circ} \mathrm{C}$ resulted in the disappearance of silica due to its complete reaction with lime and Al. Clear formation of Anhydrite $\left(\mathrm{CaSO}_{4}\right)$ as a result of reaction between $\mathrm{SO}_{3}$, produced from combustion of organic matter, and $\mathrm{CaO}$ resulted from calcite decomposition. Quite similar results have been reported for ashing El-Lajjun OS from central Jordan by Al-Harahsheh et al. [14]. One interesting point is the clear formation of cement materials like, Portland cement $\mathrm{Ca}_{3} \mathrm{SiO}_{5}+\mathrm{Ca}_{2} \mathrm{SiO}_{4}$.

$$
\begin{aligned}
2 \mathrm{CaO}+\mathrm{SiO}_{2} & \rightarrow \mathrm{Ca}_{2} \mathrm{SiO}_{4} \\
3 \mathrm{CaO}+\mathrm{SiO}_{2} & \rightarrow \mathrm{Ca}_{3} \mathrm{SiO}_{5} \\
\mathrm{CaO}+\mathrm{SO}_{3} & \rightarrow \mathrm{CaSO}_{4}
\end{aligned}
$$

The chemistry of the ashed samples at different ashing temperatures is presented in Table 3 and Table 4. Different ashing temperature resulted in different ash chemistry. With increasing ashing temperature, the concentration of the measured mineral oxides increases as loss of ignition (L.O.I) decreased. Complete OM combustion is achieved at higher ashing temperatures.

\section{3. $\mathrm{pH}$ and Conductivity of OS Ash Leachate}

About $1 \mathrm{~g}$ of $\mathrm{OS}$ ashed at $750^{\circ} \mathrm{C}$ was soaked in distilled water and agitated at $700 \mathrm{rpm}$. The values of $\mathrm{pH}$ and conductivity obtained at different conditions are shown in Figure 5. Generally, the $\mathrm{pH}$ of the leachate is as high as about 12 suggesting the alkalinity na- 
Table 3. The chemistry of the ashed samples as obtained by the XRF technique.

\begin{tabular}{|c|c|c|c|c|c|c|c|c|c|c|c|}
\hline Type & $\begin{array}{c}\mathrm{Fe}_{2} \mathrm{O}_{3} \\
\%\end{array}$ & $\begin{array}{c}\mathrm{MnO} \\
\%\end{array}$ & $\begin{array}{c}\mathrm{TiO}_{2} \\
\%\end{array}$ & $\begin{array}{c}\mathrm{CaO} \\
\%\end{array}$ & $\begin{array}{c}\mathrm{K}_{2} \mathrm{O} \\
\%\end{array}$ & $\begin{array}{c}\mathrm{P}_{2} \mathrm{O}_{5} \\
\%\end{array}$ & $\begin{array}{c}\mathrm{SiO}_{2} \\
\%\end{array}$ & $\begin{array}{c}\mathrm{Al}_{2} \mathrm{O}_{3} \\
\%\end{array}$ & $\begin{array}{c}\mathrm{MgO} \\
\%\end{array}$ & $\begin{array}{c}\mathrm{Na}_{2} \mathrm{O} \\
\%\end{array}$ & $\begin{array}{c}\text { L.O.I } \\
\%\end{array}$ \\
\hline Ash $550^{\circ} \mathrm{C}$ & 2.584 & 0.012 & 0.265 & 40.484 & 0.280 & 1.697 & 17.06 & 8.702 & 0.631 & 0.278 & 28.00 \\
\hline Ash $950^{\circ} \mathrm{C}$ & 3.604 & 0.013 & 0.329 & 51.451 & 0.336 & 2.329 & 24.04 & 12.390 & 0.888 & 0.556 & 04.05 \\
\hline
\end{tabular}

Table 4. Heavy metals content of OS and its ashes at different ashing temperatures as determined by ICP-MS.

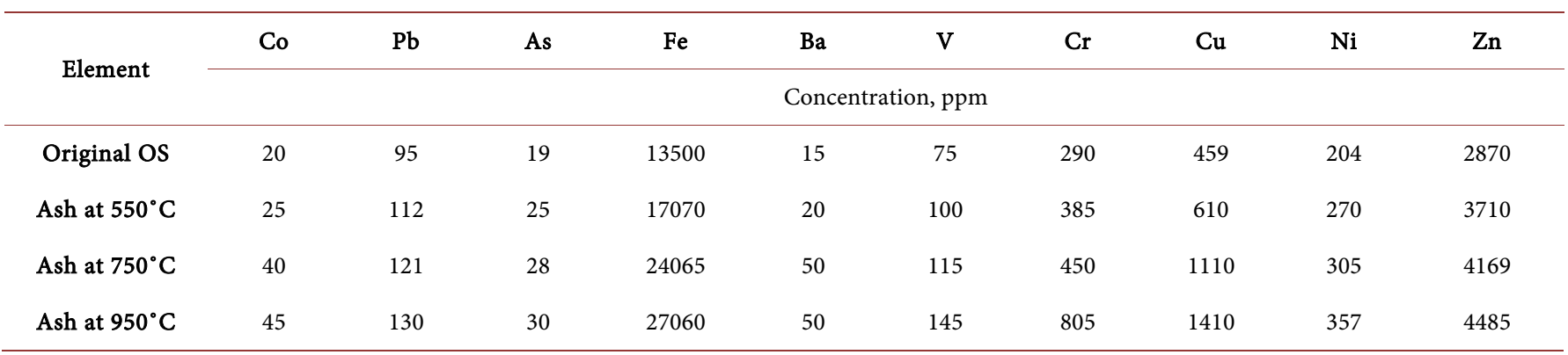
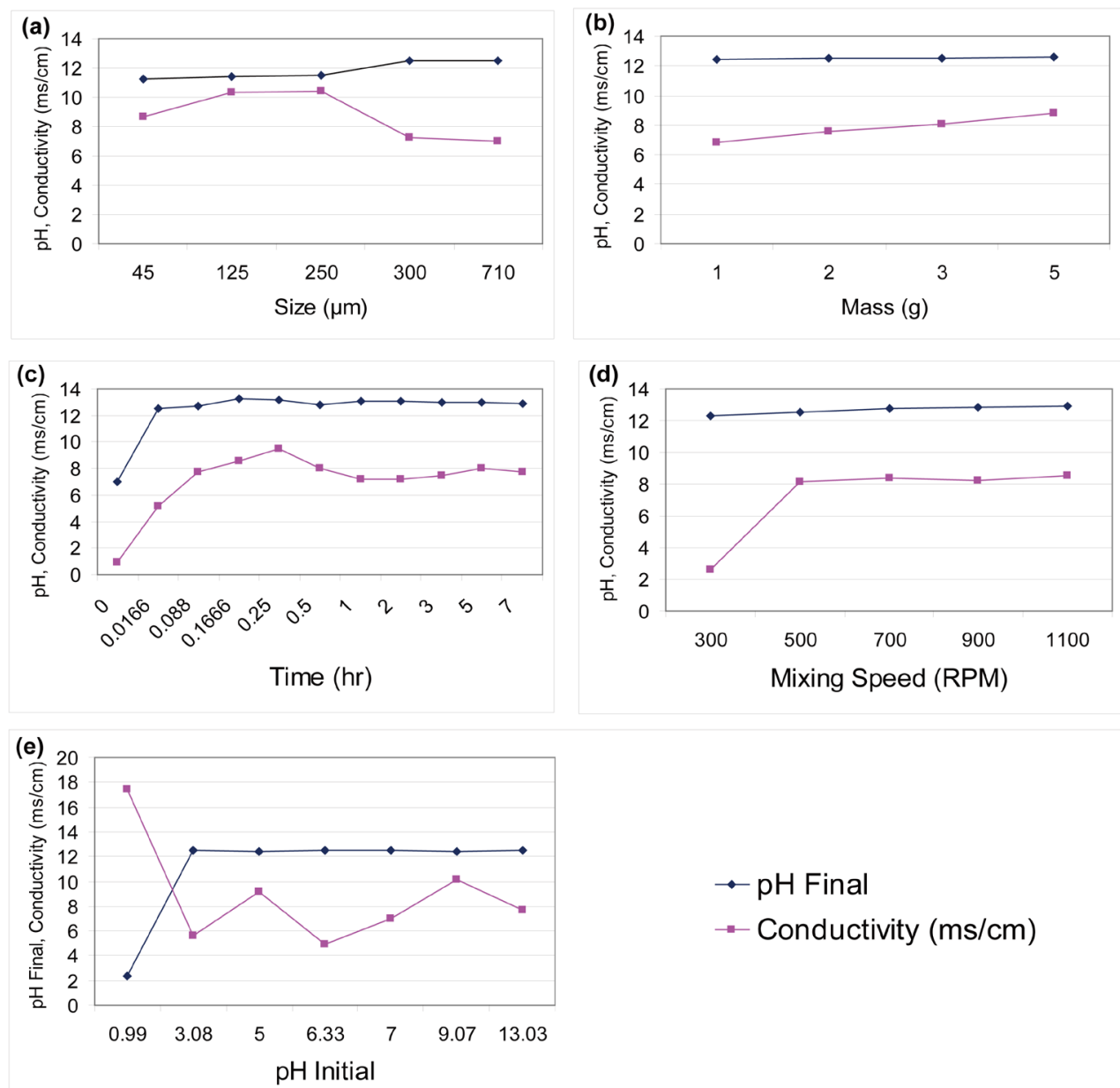

Figure 5. Investigated parameters effect on $\mathrm{pH}$ and conductivity of $\mathrm{OS}$ ash combusted at $750^{\circ} \mathrm{C}$. 
ture of OS ash. This is also evident from the mineralogy of the ash; $\mathrm{CaO}$ in water is converted to calcium hydroxide, which is slightly soluble in water (about $2 \mathrm{~g} / \mathrm{l}$ at room temperature). From the environmental point of view, high $\mathrm{pH}$ when $\mathrm{OS}$ ash $\mathrm{pH}$ is regarded as advantageous in neutralizing acidic mine drainage (AMD) [14]. The effect of particle size of OS ash on $\mathrm{pH}$ and conductivity (Figure 5(a)) shows overall slight increase in $\mathrm{pH}$ and increase in conductivity to size $250 \mu \mathrm{m}$ then decrease. Slight increase in $\mathrm{pH}$ and conductivity observed as a result of OS ash mass increase (Figure 5(b)); the conductivity increases faster than $\mathrm{pH}$ in this case. This is due to the fact that $\mathrm{pH}$ is a measure of $\left[\mathrm{H}^{+}\right]$, whereas, the conductivity is a measure of the concentration of all ions present in the solution. Off course the more ash mass in solution the more are the ions present in solution.

Results show that the $\mathrm{pH}$ and conductivity increases as a result of mixing time increase (Figure 5(c)). As mixing time increase, the compounds and ions have enough time to soluble in solution resulted in the $\mathrm{pH}$ and conductivity increase. However, one can observe that the conductivity of the solution deceases slightly after 30 min mixing time, and then remains almost constant. This reduction in conductivity value could be related to the precipitation of some compounds such as $\mathrm{CaCO}_{3}$ [14] [18] [19]. The presence of $\mathrm{CO}_{2}$ available in surrounding atmosphere (the vessel was open) dissolves in the slurry solution, resulting in the $\mathrm{CO}_{2}$ dissolution which can reacts with $\mathrm{Ca}$ ions in the solution to form calcium carbonate.

Slight increase in $\mathrm{pH}$ and conductivity observed due to the increase in mixing rate (Figure 5(d)). The effect of $\mathrm{pH}$ initial on $\mathrm{pH}$ final and conductivity is shown in (Figure $5(\mathrm{e}))$. The $\mathrm{pH}$ final sharply increases till 3.08 then slightly increases. Fluctuation in conductivity observed as $\mathrm{pH}$ initial increases.

\subsection{Heavy Metals Leachability}

Ashing OS temperature, leaching temperature, and their relation with $\mathrm{pH}$ are important factors need to be considered in heavy metal release from OS ash. The effect of ashing temperature on heavy metal release is shown in Figure 6. Results show that, in general, the release of $\mathrm{Cr}, \mathrm{Cu}, \mathrm{Ni}, \mathrm{Zn}$, and $\mathrm{Pb}$ decreases with increasing the ashing temperature. Higher release of such metals is obtained at low $\mathrm{pH}$. Within the whole ashing temperature range used, the levels of theses metals were below the levels set by the Environmental Protection Authority (EPA) for drinking water.

The effect of leaching temperature on metal release at wide range of $\mathrm{pH}$ for OS ash obtained at different ashing temperatures is shown in Figures 7-10. Generally, metal release is minor. More metal release is obtained at low $\mathrm{pH}$. With increasing leaching temperatures, OS ashes show different patterns of metal release. At low $\mathrm{pH}$, the leachability of the heavy metals analyzed is higher than those at higher $\mathrm{pH}$. Analysis result on the effect of initial $\mathrm{pH}$ on final $\mathrm{pH}$ of the leachate (see Figure 11) suggests that irrespective of initial $\mathrm{pH}$, except at initial $\mathrm{pH}<1$ (final $\mathrm{pH}=2.4$ ), the final $\mathrm{pH}$ is above 12 . The acidic environment may be the reason for high metal release from the ash. Chromium and lead are the most released heavy metals with the exception at low $\mathrm{pH}$, where 

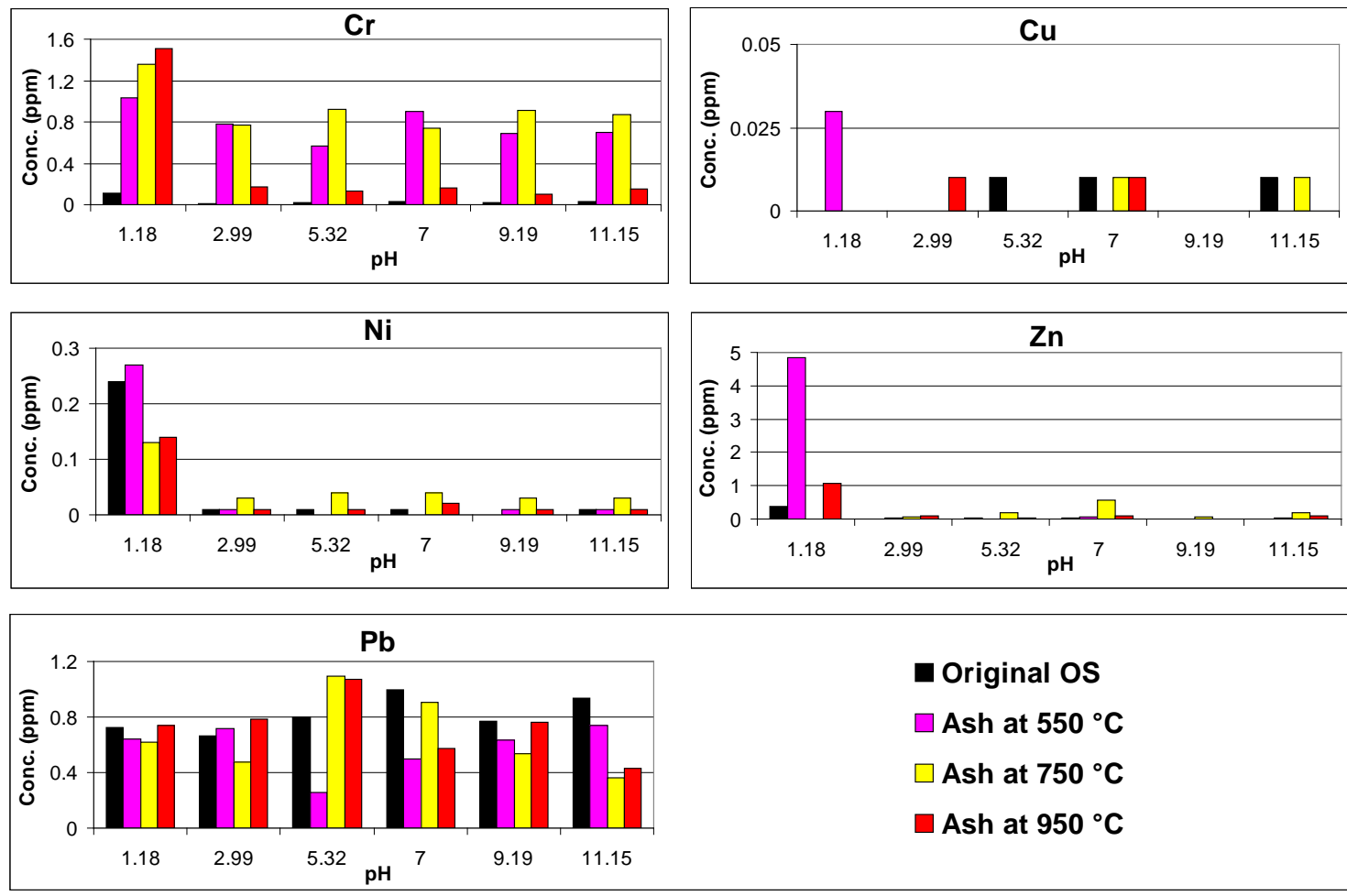

- Original os

$\square$ Ash at $550^{\circ} \mathrm{C}$

$\square$ Ash at $750^{\circ} \mathrm{C}$

ash at $950^{\circ} \mathrm{C}$

Figure 6. Effect of ashing temperature.
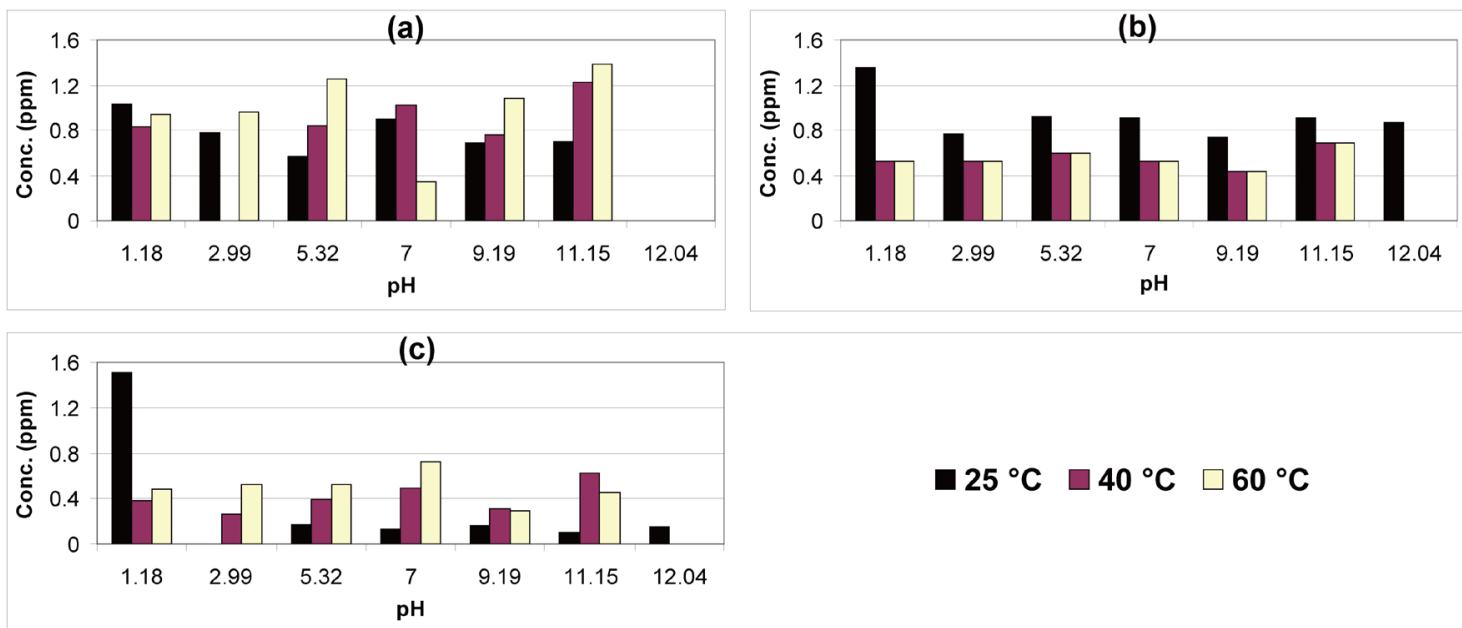

$25^{\circ} \mathrm{C} \quad \square 40^{\circ} \mathrm{C} \quad \square 60^{\circ} \mathrm{C}$

Figure 7. Concentration of $\mathrm{Cr}(\mathrm{ppm})$ in the leachate as determined by ICP. (a) Ash at $550^{\circ} \mathrm{C}$, (b) ash at $750^{\circ} \mathrm{C},(\mathrm{c})$ ash at $950^{\circ} \mathrm{C}$.

it is found that all metals higher release. It is also interesting to note that the release of $\mathrm{Cr}$ from both original OS and OS ash obtained at $950^{\circ} \mathrm{C}$ are lower than that obtained at OS ashes obtained at $550^{\circ} \mathrm{C}$ and $750^{\circ} \mathrm{C}$. This could be related to the fact that $\mathrm{Cr}$ in the first instance are fixed with the crystalline structure of the mineral phases, whereas, it could available for leaching in a matrix obtained at moderate ashing temperatures where better chances to find easy leachable amorphous phases. Never less, heavy metals 


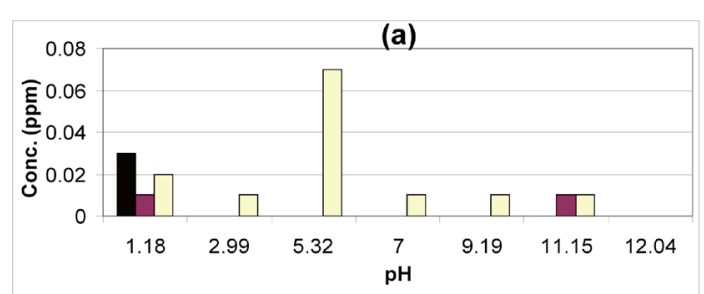

(c)

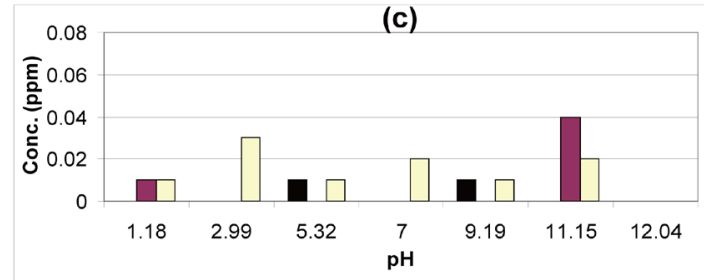

(b)

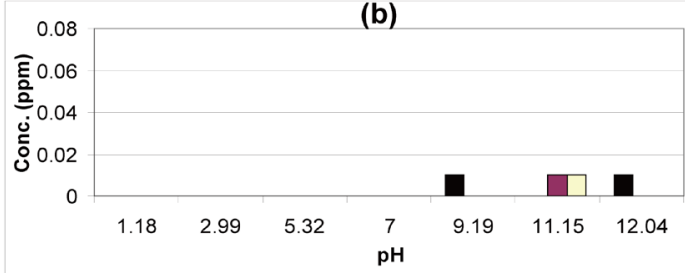

$\square 25^{\circ} \mathrm{C} \quad \square 40^{\circ} \mathrm{C} \quad \square 60^{\circ} \mathrm{C}$

Figure 8. Concentration of $\mathrm{Cu}(\mathrm{ppm})$ in the leachate as determined by ICP. (a) Ash at $550^{\circ} \mathrm{C}$, (b) ash at $750^{\circ} \mathrm{C},(\mathrm{c})$ ash at $950^{\circ} \mathrm{C}$.
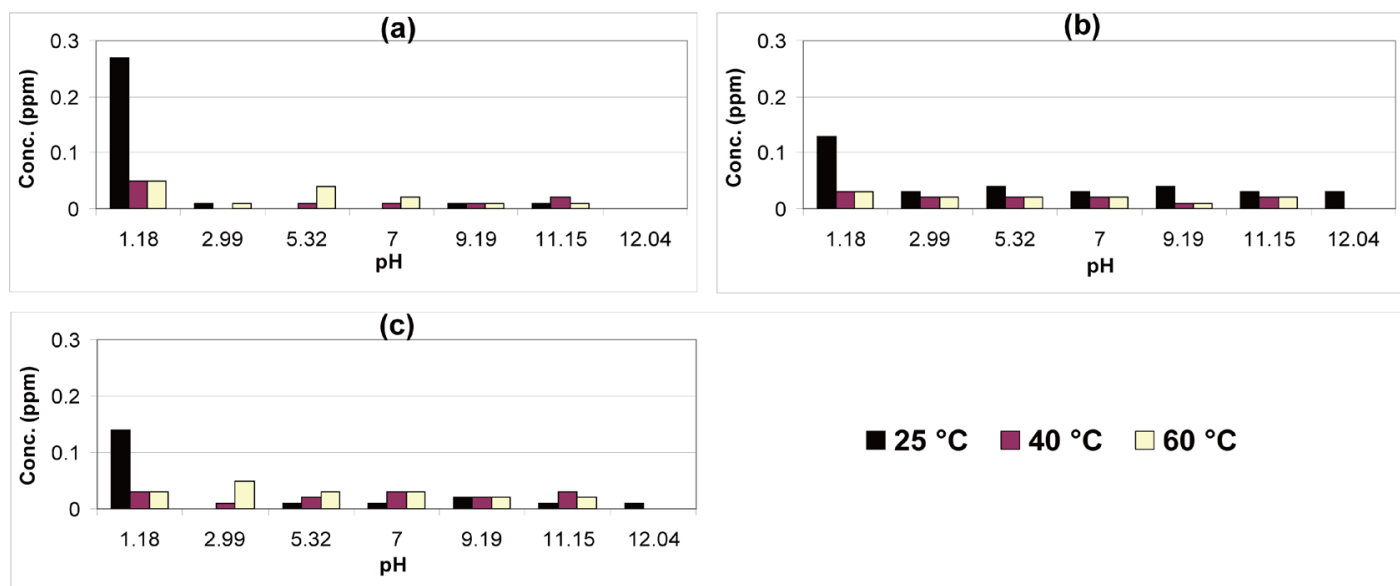

$\square 25^{\circ} \mathrm{C} \square 40^{\circ} \mathrm{C} \quad \square 60^{\circ} \mathrm{C}$

Figure 9. Concentration of $\mathrm{Ni}(\mathrm{ppm})$ in the leachate as determined by ICP. (a) Ash at $550^{\circ} \mathrm{C}$, (b) ash at $750^{\circ} \mathrm{C},(\mathrm{c})$ ash at $950^{\circ} \mathrm{C}$.
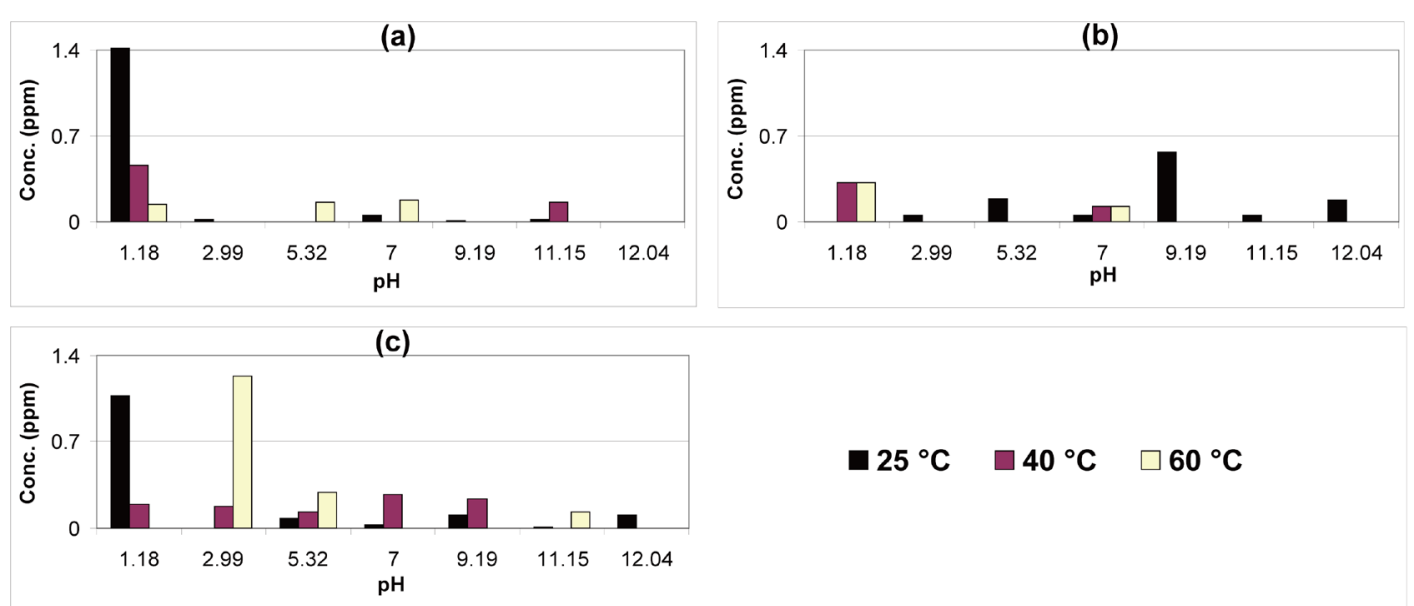

$\square 25^{\circ} \mathrm{C} \quad \square 40^{\circ} \mathrm{C} \quad \square 60^{\circ} \mathrm{C}$

Figure 10. Concentration of $\mathrm{Zn}(\mathrm{ppm})$ in the leachate as determined by ICP. (a) Ash at $550^{\circ} \mathrm{C}$, (b) ash at $750^{\circ} \mathrm{C},(\mathrm{c})$ ash at $950^{\circ} \mathrm{C}$. 


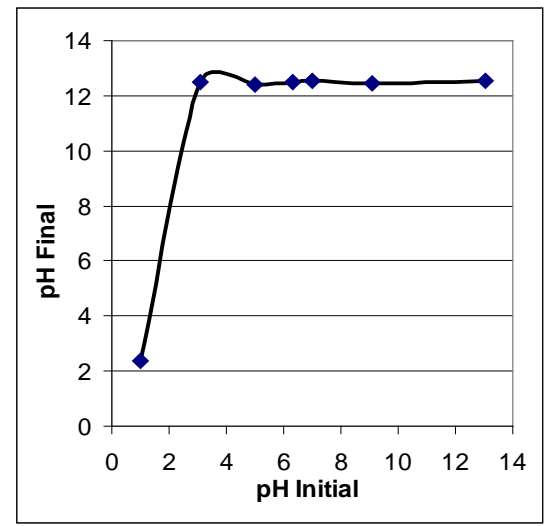

Figure 11. Effect of $\mathrm{pH}$ initial on $\mathrm{pH}$ final of the leachate $(\mathrm{V}=100 \mathrm{ml}$, mass $=1 \mathrm{~g}, \mathrm{rpm}=700$, size $=710-1400 \mu \mathrm{m}, \mathrm{t}=5 \mathrm{hrs}$, ashing $\mathrm{T}=$ $\left.750^{\circ} \mathrm{C}\right)$.

in OS ash are immobile and will not be easily leached to the groundwater by the action of water infiltration. Agitated mixtures resulted in slight leaching of these metals in the present case [5]. Leaching conditions are very important [11].

\section{Conclusion}

Characterization results of Jordanian Isfir Al-Mahata OS deposit show that the OS has TOC content of $8 \%$. The mineral constituents are calcite, silica as quartz, phosphates as apatite, and minor amounts of clay minerals and pyrite. The average $\mathrm{CaO}$ and $\mathrm{SiO}_{2}$ content is 28.65 and $11.64 \%$, respectively. Oil shale ash was also examined and characterized. Ashing OS at $550^{\circ} \mathrm{C}$ did not result in any major change in the mineralogical composition. Ashing $\mathrm{OS}$ at $750^{\circ} \mathrm{C}$ resulted in the appearance of calcium silicate and aluminium silicate and lime, and the disappearance of calcite. Ashing $\mathrm{OS}$ at $950^{\circ} \mathrm{C}$ resulted in the disappearance of silica, due to its complete reaction with lime and $\mathrm{Al}$, and clear formation of Anhydrite cement materials like, Portland cement $\mathrm{Ca}_{3} \mathrm{SiO}_{5}+$ $\mathrm{Ca}_{2} \mathrm{SiO}_{4}$. The leachability of heavy metals shows that for most elements the leachability is high at low $\mathrm{pH}$. The leachability of $\mathrm{Cr}, \mathrm{Cu}, \mathrm{Ni}, \mathrm{Zn}$, and $\mathrm{Pb}$ is below EPA limits. Chromium and lead are leached out more than other elements with the exception at low $\mathrm{pH}$. In general, the higher the ashing temperature is, the lower the release of elements is.

\section{References}

[1] Besieso, M. (2007) Jordan's Commercial Oil Shale Strategy. 27th Oil Shale Symposium, Colorado, 15-19 October 2007, 12 p.

[2] Alali, J. (2006) Jordan Oil Shale, Availability, Distribution, and Investment Opportunity. The NRA, Jordan. Rtos-A117.

[3] Powell, J. (1989) Stratigraphy and Sedimentation of the Phanerozoic Rocks in Central and South Jordan Part B Kurnub, Ajlun and Belqa Groups. Natural Resources Authority 1:50,000. Geological Mapping Series, Geological Bulletin No. 11.

[4] Alnawafleh, H.M. (2007) Geological Factors Controlling the Variability of Maastrichtian 
Bituminous Rocks in Jordan. PhD Thesis. The University of Nottingham. Nottingham.

[5] Ibrahim, K. and Jaber, J.O. (2007) Geochemistry and Environmental Impacts of Retorted Oil Shale from Jordan. Environmental Geology, 52, 979-984.

http://dx.doi.org/10.1007/s00254-006-0540-6

[6] Jaber, J.O., Sladek, T.A., Mernitz, S. and Tarawneh, T.M. (2008) Future Policies and Strategies for Oil Shale Development in Jordan. Jordan Journal of Mechanical and Industrial Engineering, 2, 31-44.

[7] Smadi, M. and Haddad, R. (2003) The Use of Oil Shale Ash in Portland Cement Concrete. Cement \& Concrete Composites, 25, 43-50. http://dx.doi.org/10.1016/S0958-9465(01)00054-3

[8] Tamm, K., Kuusik, R., Uibu, M. and Kallas, J. (2013) Transformations of sulfur Compounds in Oil Shale Ash Suspension. Energy Procedia, 37, 5905-5912. http://dx.doi.org/10.1016/j.egypro.2013.06.516

[9] Häsänen, E., Aunela-Tapola, L., Kinnunen, V., Larjava, K., Mehtonen, A., Salmikangas, T., Leskelä, J. and Loosaar, J. (1997) Emission Factors and Annual Emissions of Bulk and Trace Elements from Oil Shale Fueled Power Plants. Science of the Total Environment, 198, 1-12. http://dx.doi.org/10.1016/S0048-9697(97)05432-6

[10] Kisel, E. (1999) Large Investments of Oil Shale Fired Power Stations Are Directed towards Environmental Protection. Environmental Engineering, 3, 24-25.

[11] Adamson, J., Irha, N., Adamson, K., Steinnes, E. and Kirso, U. (2010) Effect of Oil Shale Ash Application on Leaching Behaviour of Arable Soils: An Experimental Study. Oil Shale, 27, 250-257. http://dx.doi.org/10.3176/oil.2010.3.06

[12] Han, X., Kulaots, I., Jiang, X. and Suuberg, E.M. (2014) Review of Oil Shale Semicoke and Its Combustion Utilization. Fuel, 126, 143-161. http://dx.doi.org/10.1016/j.fuel.2014.02.045

[13] Jankowski, J., Ward, C. R., French, D. and Groves, S. (2006) Mobility of Trace Elements from Selected Australian Fly Ashes and Its Potential Impact on Aquatic Ecosystems. Fuel, 85, 243-256. http://dx.doi.org/10.1016/j.fuel.2005.05.028

[14] Al-Harahsheh, A., Al-Otoom, A., Al-Harahsheh, M., Allawzi, M., Al-Adamat, R. and AlFarajat, M. (2012) The Leachability Propensity of El-Lajjun Jordaninan Oil Shale Ash. Jordan Journal of Earth and Environmental Sciences (JJEES), 4, 29-34.

[15] Alnawafleh, H., Tarawneh, K., Ghannam, A. and Abu-Sa'ad, L. (2013) Isfir Al-Mahata: A Newly Discovered Subsurface Oil Shale Deposit in Southern Jordan. The Journal of Geography and Geology, 5, 12-21. http://dx.doi.org/10.5539/jgg.v5n3p12

[16] Jaber, J.O., Probert, S.D. and Williams. P.T. (1999) Evaluation of Oil Yield from Jordanian Oil Shales. Energy, 24, 761-781. http://dx.doi.org/10.1016/S0360-5442(99)00029-8

[17] Williams, P.T. and Chishti, H.M. (2001) Reaction of Nitrogen and Sulphur Compounds during Catalytic Hydro Treatment of Shale Oil. Fuel, 80, 957-963.

http://dx.doi.org/10.1016/S0016-2361(00)00189-7

[18] Cizer, O., Van Balen, K., Elsen, J. and Van Gemert, D. (2008) Carbonation Reaction Kinetics of Lime Binders Measured Using XRD. Proceedings of ACEME08, 2nd International Conference on Accelerated Carbonation for Environmental and Materials Engineering, Rome, 1-3 October 2008, 139-148.

[19] Bruno, V., Hower, J., Flores, C.D. and Guedes, A. (2009) Laminar Calcite Aggregate Formation in the Fly Ash Fraction. World of Coal Ash (WOCA) Conference, Lexington, 4-7 May 2009. 
Submit or recommend next manuscript to SCIRP and we will provide best service for you:

Accepting pre-submission inquiries through Email, Facebook, LinkedIn, Twitter, etc. A wide selection of journals (inclusive of 9 subjects, more than 200 journals)

Providing 24-hour high-quality service

User-friendly online submission system

Fair and swift peer-review system

Efficient typesetting and proofreading procedure

Display of the result of downloads and visits, as well as the number of cited articles

Maximum dissemination of your research work

Submit your manuscript at: http://papersubmission.scirp.org/

Or contact jmmce@scirp.org 